\title{
Desulfurization of heavy crude oil by microwave irradiation
}

\author{
A. Miadonye ${ }^{1}$, S. Snow ${ }^{1}$, D. J. G. Irwin ${ }^{1}$, M. Rashid Khan ${ }^{2}$ \\ \& A. J. Britten ${ }^{1}$ \\ ${ }^{I}$ School of Science \& Technology, Cape Breton University, Canada \\ ${ }^{2}$ King Abdullah University of Science \& Technology, Saudi Arabia
}

\begin{abstract}
Heavy crude oils normally have a high sulfur content and are usually very viscous. To improve the quality of the refinery fractions and subsequent consumers' products, it is imperative to remove the impurities and contaminants and, where possible, upgrade the heavy crude oil. In this project, the desulphurization process of Arabian heavy sour crude oil was studied by a novel method of microwave irradiation. The heat transfer characteristics of various mineral additives were studied for use as microwave sensitizers. Crude oil samples containing various combinations of hydrogen donor additives, catalysts, and microwave sensitizers were studied. The samples were exposed to different irradiation periods at different power levels in a modified domestic microwave oven. The results indicate that crude oil microwave absorption characteristics can be improved fourfold with charcoal and doubled with polar solvents, but they showed negligible change with serpentine, due to poor hear transfer properties. The sulfur content of the original crude oil was reduced by $2.3 \%$ with $\mathrm{H}_{2}$ at 20 atmosphere pressure and 5 minutes irradiation period; and by $33.8 \%$ with ethanolamine as the hydrogen donor and 25 minutes irradiation period. For the crude oil fractions, the sulfur reductions were up to $48 \%$ and $10 \%$ for lighter and heavier fractions respectively. Analysis with GC-FID showed strong evidence of fragmentation and recombination reactions in samples irradiated for 20 and 25 minutes with a temperature of $300^{\circ} \mathrm{C}$ and above.
\end{abstract}

Keywords: crude oil desulfurization, microwave irradiation, petroleum upgrading, hydro-desulfurization, microwave sensitizers. 


\section{Introduction}

The application of radiation chemistry in the oil industry gained prominence in the early 1960s when only light hydrocarbon substances were used as models in radiation processing experiments [1, 2]. Radiation processing was rather expensive then and it was not until the 1990s that the concept of the 'hydrocarbon enhancement electron-beam technology' (HEET) was developed. More recently, microwave irradiation has been used in the petroleum industry for inspecting coiled tubing and line pipes, measuring multiphase flow, and the mobilization of asphaltic crude oil [2-5]. Gunal and Islam [3] observed the permanent alteration of asphaltene in the colloidal structures of the crude oil molecules and an increase in viscosity when exposed to microwave irradiation, due to the re-orientation of molecular structures rather than thermal breakdown. They noted that when exposed to electromagnetic irradiation, the presence of asphaltene caused permanent changes in crude oil rheology due to the polar nature of asphaltene molecules. Zaykin et al. [6, 7] reported the evidence of much branching and breaking of the paraffin chain during irradiation of paraffinic oil. Thus, microwave heating has been identified to offer numerous advantages, such as short start up time, rapid heating, energy efficiency, and precise process control.

Microwave energy can be delivered directly to the reacting or processing species by using their dielectric properties or by adding absorbing material, which converts electromagnetic energy into heat. Thus, microwave energy has the ability to crack hydrocarbons and create a method of desulphurization. The sulfur content in heavy crude oil varies from $0.1 \%$ to $15 \%$, and most is heavy molecular organic sulfur compounds - any dissolved elemental sulfur and/or hydrogen sulfide represent only a small part of the total sulfur. The sulfur containing compounds in crude oil have been identified to include the following compounds: sulfides, disulfides, mercaptans (thiophenes), benzothiophenes, dibenzothiophenes, benzonaphthothiophenes, and dinaphthothiophenes [8]. Desulphurization of crude oil is an important preliminary step to improve the quality and yield of gasoline products. Currently, the method of desulphurization in the chemical industry has fundamental limitations, such as costly energy and material consumption, extreme processing conditions and expensive catalysts. New products and processing routes are continually being sought including current methods in microwave irradiation. Through the use of microwave power, along with additives, hydrocarbons high in sulfur content and/or composed of primarily heavy hydrocarbons can be made into useful commercial products that can be burned cleanly and efficiently as a fuel oil, as demonstrated in several patents for the use of microwave irradiation [9].

\section{Experimental methods}

The experiments involved the reconstruction of a domestic microwave to accommodate the devices required for monitoring the irradiation process, and the analysis of the reaction products using appropriate analytical instrumentation. 


\subsection{Microwave set-up and irradiation process}

The desulphurization process was carried out in a domestic microwave oven which was modified to allow for the accommodation of high temperature and moderate pressure reactors, mixing device, and a device for reconstitution of volatile fractions. Also included in the modification was a provision for monitoring the temperature and pressure of the process. In a typical experiment, Saudi Arabia heavy crude was mixed with one or more of hydrogen, light hydrocarbon liquid, polar additives, hydrotreating catalysts, microwave sensitizers, and exposed to various dosages of microwave radiation at low pressure. The selection of microwave sensitizers was based on their dielectric constant obtained from literature [10]. The power level and irradiation intensity was at level high (recorded in this microwave oven as Power Level 10), and the maximum irradiation period was 25 minutes. Table 1 illustrates the different samples used in the process. Polar additives used were ethanolamines, to examine their influence on desulphurization and, on the microwave radiation characteristics of the Saudi Arabia heavy crude oil.

Table 1: $\quad$ List of materials.

\begin{tabular}{|l|l|}
\hline Arabian Heavy Crude Oil & $\begin{array}{l}{ }^{\circ} \text { API }(27.31) ; \\
\text { Sulfur content }(3.066 \%)\end{array}$ \\
\hline Pure Hydrogen Gas & \\
\hline Activated Charcoal & Sensitizer \\
\hline Palladium Oxide & Catalyst \\
\hline Serpentine & Sensitizer \\
\hline Ethanolamines & Polar Additives \\
\hline $\begin{array}{l}\text { Mongstad, Norway Crude } \\
\text { Oil }\end{array}$ & Model Compound \\
\hline
\end{tabular}

\subsection{Analytical methods}

The products formed after irradiation and the control samples were analyzed using Gas Chromatography with Flame Ionization Detector (GC-FID), GC with Mass Spectrometry (GC-MS), and Fourier Transform Infrared (FT-IR) spectroscopy among other analytical methods. The GC instrument is a 5890 Series II Plus Gas Chromatograph coupled with a FID and a 5872 Mass Selective Detector (MS) fitted with a fused silica capillary column. The column contained the non-polar stationary phase used for simulated distillation analyses (ICB-1, $30 \mathrm{mx} 0.25 \mathrm{~mm}$ ID, $0.25 \mu \mathrm{m}$ film thickness; J \& K Scientific, Milton, Ontario, Canada). The initial column temperature $70^{\circ} \mathrm{C}$, held for 1 minute, then increased at a rate of $30^{\circ} \mathrm{C} / \mathrm{min}$ to $310^{\circ} \mathrm{C}$ and held for 1 minute. The injection volume was $0.5 \mu 1$. The carrier gas was ultra-high purity hydrogen (from Air Liquide Canada, Sydney, Nova Scotia, Canada) at an initial pressure of $4.1 \mathrm{psi}\left(\right.$ at $70^{\circ} \mathrm{C}$ ) and flow rate of $0.50 \mathrm{ml} / \mathrm{min}$. The FID was held at $350^{\circ} \mathrm{C}$ with $\mathrm{H}_{2}$ at $35 \mathrm{ml} / \mathrm{min}$; air, 350 
$\mathrm{ml} / \mathrm{min}$, make-up $\mathrm{N}_{2}, 25 \mathrm{ml} / \mathrm{min}$. The MS interface temperature was $320^{\circ} \mathrm{C}$. It was operated in the scan mode (50-550 amu) with 1-minute solvent delay period. Each analysis was 10 minutes. Carbon standards were analyzed and retention times of n-C5, 10,15,20,25 and 30 were determined.

\section{Results and discussion}

The physical properties of the pure (original) heavy crude oil were determined. The ${ }^{\circ}$ API was obtained by hydrometer to be 27.31 , with sulfur content of 3.066 per cent and viscosity of $34.84 \mathrm{cSt}$ at $25.2^{\circ} \mathrm{C}$. The distillation fractions of the pure heavy crude oil obtained between $154^{\circ} \mathrm{C}$ and $452^{\circ} \mathrm{C}$ for 50 gram sample and their mass per cent of sulfur contents before and after microwave irradiation are compared in Table 2. The sulfur contents of the light distillates were reduced to $39 \%$ and $48 \%$, while those of heavy distillates were reduced to $0.9 \%$ and $10 \%$. The results showed approximately $50 \%$ desulphurization can be achieved in the lighter fractions.

\subsection{Effects of sensitizers and additives in hydro-desulfurization}

The main purpose of hydro-desulphurization (HDS) is to improve the quality of the heavy crude oil and thus, meeting the required specifications for its particular

Table 2: $\quad$ Sulfur content analysis for the fractions.

\begin{tabular}{|c|c|c|c|c|}
\hline Distillation & Temp & Irradiation & \multicolumn{2}{|c|}{ Mass \% sulfur } \\
\hline $\begin{array}{l}\text { Fractions } \\
(50 \mathrm{~g})\end{array}$ & $\left({ }^{\circ} \mathrm{C}\right)$ & $\begin{array}{l}\text { Time } \\
\text { (mins) }\end{array}$ & $\begin{array}{c}\text { Non- } \\
\text { irradiated }\end{array}$ & $\begin{array}{c}\text { Irradiated for } 10 \\
\text { mins with } \\
\text { catalyst }\end{array}$ \\
\hline 1 & $\begin{array}{c}154.5 \text { to } \\
250.0\end{array}$ & 10 & 1.859 & $0.9624(\mathbf{4 8 . 3 \%})$ \\
\hline 2 & $\begin{array}{c}260.0 \text { to } \\
306.2\end{array}$ & 10 & 0.3110 & $0.1902(\mathbf{3 8 . 8 \%})$ \\
\hline 3 & $\begin{array}{c}318.2 \text { to } \\
380.1\end{array}$ & 13 & 0.9030 & $\begin{array}{l}0.8128 \\
(\mathbf{1 0 \%})\end{array}$ \\
\hline 4 & $\begin{array}{c}396.4 \text { to } \\
452.2\end{array}$ & 25 & 2.528 & $\begin{array}{c}2.506 \\
(\mathbf{0 . 8 9 \%})\end{array}$ \\
\hline
\end{tabular}


use. Depending on the process conditions the HDS process can be classified as "destructive" or "non-destructive". The destructive HDS process is characterized by molecular fragmentation and hydrogenation saturation of the fragments to produce lower boiling fractions, and the non-destructive HDS process requires milder conditions (referred to as hydrotreating) and provides a means of removing simple souring compounds [8]. In the microwave irradiation process it is difficult to meet the requirements of the HDS destructive process in the absence of sensitizers. The prevailing conditions in microwave process generally favor non-destructive HDS due to the low temperature conditions obtainable with microwave irradiation. Since crude oil absorbs little microwave radiation, sensitizers and other polar solvents have been used to improve its absorption. As indicated in Figure 1, the presence of sensitizers and additives improved absorption by the oil of microwave radiation, identified by the increase in the temperature of the oil.

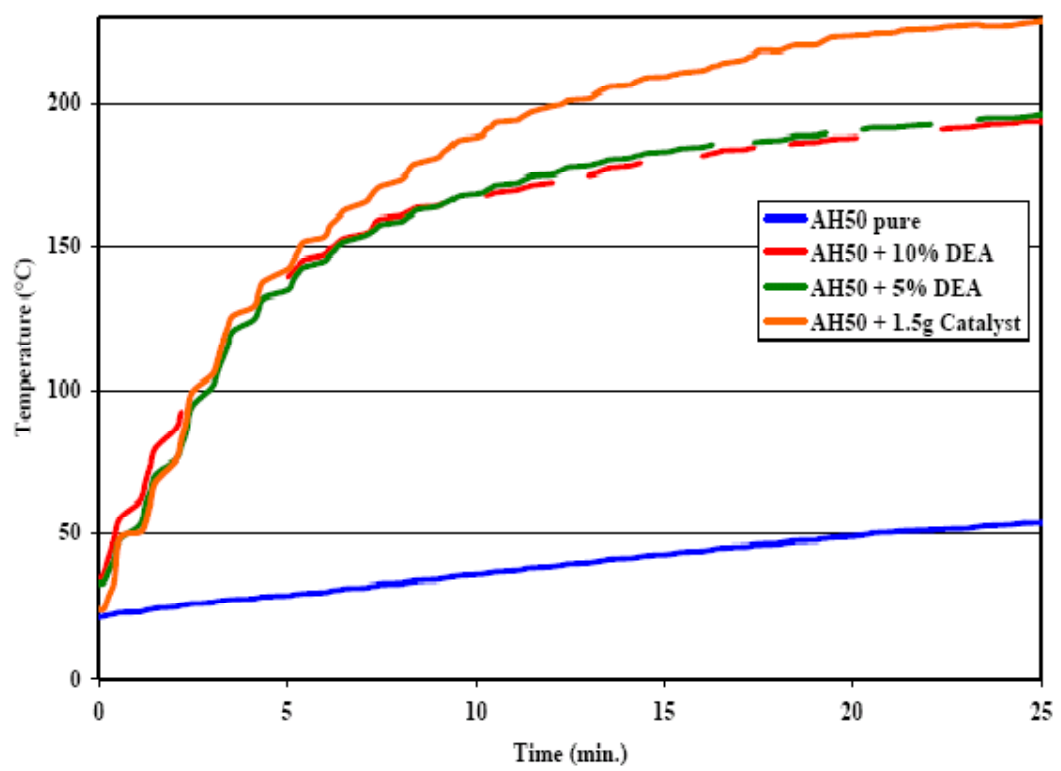

Figure 1: Microwave absorption characteristics of heavy crude oil with and without additives.

To ascertain the amount of power absorbed by the charcoal and serpentine used as sensitizers, the energy absorbed at Power Level 10 by $60 \mathrm{ml}$ water core immersed in $650 \mathrm{ml}$ crude oil jacket was measured. Each sensitizer was incrementally added into the crude oil jacket and irradiated for a prescribed period. Table 3 illustrates the microwave absorption characteristics of the sensitizers as given by the average power absorbed by the oil in the jacket. It is evident from the results that serpentine is a poor microwave sensitizer with 73 Watts (perhaps this is unique with the type of serpentine used for this experiment 
Table 3: $\quad$ Microwave absorption characteristics of the sensitizers.

\begin{tabular}{|l|l|c|c|c|}
\hline \multicolumn{1}{|c|}{ Samples } & Composition & \multicolumn{1}{|c|}{$\begin{array}{c}\text { Final } \\
\text { Temperature } \\
\left({ }^{\circ} \mathrm{C}\right)\end{array}$} & $\begin{array}{c}\text { Irradiation } \\
\text { Time(s) }\end{array}$ & $\begin{array}{c}\text { Power } \\
\text { (Watt) }\end{array}$ \\
\hline $\begin{array}{l}\text { AH50 } \\
\text { (original } \\
\text { crude) only }\end{array}$ & $\begin{array}{l}650 \mathrm{ml} \\
\text { crude oil }\end{array}$ & 32.2 & 90 & 100 \\
\hline $\begin{array}{l}\text { AH50 }+ \\
60 \mathrm{~g} \\
\text { charcoal }\end{array}$ & $\begin{array}{l}650 \mathrm{ml} \text { oil and } \\
\text { charcoal }\end{array}$ & 91.8 & 90 & 975 \\
\hline $\begin{array}{l}\text { AH50 }+ \\
40 \mathrm{~g} \\
\text { charcoal }+ \\
60 \mathrm{ml} \text { water }\end{array}$ & $\begin{array}{l}\text { water tube in } \mathrm{ml} \text { oil } \\
\text { oil: } 33.2 \\
\text { water: } 102.0\end{array}$ & 45 & $\begin{array}{l}\text { oil: } 383 \\
\text { water: } 461\end{array}$ \\
\hline $\begin{array}{l}\text { AH50 }+ \\
20 \mathrm{~g} \\
\text { charcoal }+ \\
60 \mathrm{ml} \text { water }\end{array}$ & $\begin{array}{l}650 \mathrm{ml} \text { oil } \\
\text { water tube in }\end{array}$ & $\begin{array}{l}\text { oil: } 28.3 \\
\text { water: } 101.0\end{array}$ & 43 & $\begin{array}{l}\text { oil: } 241 \\
\text { water: } 476\end{array}$ \\
\hline $\begin{array}{l}\text { AH50+ } \\
3.25 \mathrm{~g} \\
\text { serpentine }\end{array}$ & $\begin{array}{l}650 \text { ml oil }+ \\
\text { serpentine }\end{array}$ & 30.8 & 90 & 73 \\
\hline
\end{tabular}

as their composition varies depending on location). The activated charcoal however, improved the microwave absorption characteristics of the crude oil from 100 to 975 Watts and thus, one of the effective sensitizers for crude oil.

The non-irradiated sample was also pressurized with pure hydrogen gas at 20 and 30 atmosphere pressure and then heated in a high pressure steel reactor and maintained at $84.5^{\circ} \mathrm{C}$ and $100^{\circ} \mathrm{C}$ respectively for 30 minutes over a palladiumsilica based catalyst. The results of sulfur analysis are given in Table 4 for the heavy oil and Table 2 for the fractions. The change in the sulfur content for the samples that were subjected to high pressure hydro-desulphurization reaction in the autoclave heating was negligible, between $1.8 \%$ and $2.3 \%$, compared to $16 \%$ and $33 \%$ for irradiated samples as shown in Table 4.

In agreement with the required process conditions for hydro-desulphurization discussed above, it is obvious that the temperatures for the autoclave process were too low to initiate the reaction for effective reduction in sulfur content of the heavy oil. On the other hand, for irradiated samples desulphurization was not much affected by high temperature as it was with irradiation periods, with the optimum period being 25 minutes for $33.8 \%$ desulphurization. The results showed that ethanolamine has potential as a desulphurization agent for sour crude oil.

\subsection{Effects of irradiation on heavy oil composition}

The samples exposed to five different microwave irradiation periods; $0,5,10$, 15, 20, and 25 minutes were analyzed using GC-FID and GC-MS. The results 
from the analysis showed no change in molecular structure for majority of the samples after being subjected to microwave irradiation. At irradiation temperatures of up to $300^{\circ} \mathrm{C}$, corresponding to approximately $590 \mathrm{KJ} / \mathrm{kg}$, there was no noticeable change in molecular structure for the different samples as shown with the GC-FID analysis (Figure 2). The desired enthalpy to achieve breaking of the hydrocarbon bonds may not have been obtained at these temperatures.

Table 4: $\quad$ Sulfur content of the heavy crude after irradiation.

\begin{tabular}{|c|c|c|c|c|}
\hline Samples & $\begin{array}{l}\text { Temp. } \\
\left({ }^{\circ} \mathrm{C}\right)\end{array}$ & $\begin{array}{l}\text { Irradiation } \\
\text { Time(min) }\end{array}$ & $\begin{array}{c}\text { Sulfur } \\
\text { Content }(\%)\end{array}$ & $\begin{array}{l}\% \text { Sulfur } \\
\text { Reduction }\end{array}$ \\
\hline Heavy oil (AH50) only & - & - & 3.066 & - \\
\hline $\begin{array}{c}\text { AH50- } \\
\mathrm{PM}(10 \%) \mathrm{H}_{2}=30 \mathrm{~atm}\end{array}$ & 84.5 & $\begin{array}{l}\text { autoclave } \\
\text { heating }\end{array}$ & 3.011 & 1.8 \\
\hline $\begin{array}{c}\text { AH50- } \\
\mathrm{PM}(10 \%) \mathrm{H}_{2}=20 \mathrm{~atm}\end{array}$ & 100 & $\begin{array}{l}\text { autoclave } \\
\text { heating }\end{array}$ & 3.012 & 1.8 \\
\hline $\begin{array}{c}\text { AH50- } \\
\operatorname{PM}(5 \%) \mathrm{H}_{2}=20 \mathrm{~atm}\end{array}$ & 84.5 & $\begin{array}{l}\text { autoclave } \\
\text { heating }\end{array}$ & 2.997 & 2.3 \\
\hline $\begin{array}{c}\text { AH50+1.5g } \\
\text { Palladium cat }\end{array}$ & 228.8 & 25 & 3.06 & $\begin{array}{c}\text { No } \\
\text { change }\end{array}$ \\
\hline $\begin{array}{c}\text { AH50+ } 10 \% \text { charcoal } \\
\text { on cat }\end{array}$ & 243.7 & 25 & $\begin{array}{c}\text { No } \\
\text { observation }\end{array}$ & - \\
\hline $\begin{array}{c}\text { AH50+10\%DEA }+15 \% \\
\text { charcoal on cat }\end{array}$ & 381.6 & 25 & 2.574 & 16.1 \\
\hline AH50-(10\%DEA) & 193.6 & 25 & 2.062 & 32.8 \\
\hline AH50-(5\%DEA) & 196.1 & 25 & 2.031 & 33.8 \\
\hline
\end{tabular}

Bond energy or enthalpy is essentially the average enthalpy change for a gas reaction to break all the similar bonds. Looking at the enthalpy attained in each reaction media (samples 1 to 6 in Table 5), it is apparent that only a few reaction medium attained the energy necessary to bring about bond cleavage. Samples number 5 and 6 have enthalpies of $601.3 \mathrm{KJ} / \mathrm{kg}$ and $762.5 \mathrm{KJ} / \mathrm{kg}$ respectively. The highest temperature achieved when using charcoal as the sensitizer was $381.6^{\circ} \mathrm{C}$ (sample number 6). The GC-FID chromatogram of this sample showed a noticeable change in molecular structure (Figure 3) compared to the chromatogram for the pure crude (sample \#1). There was an evident shift in the peaks of the chromatogram of this sample compared to that of the original heavy 


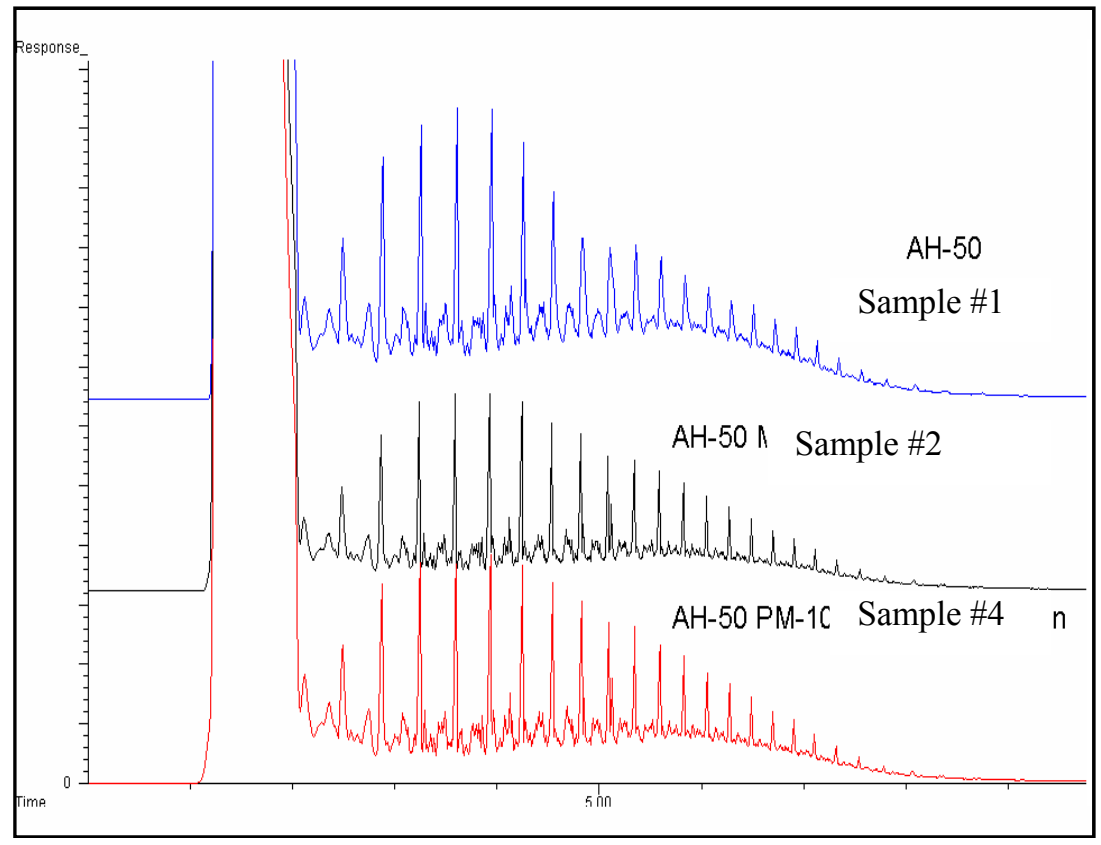

Figure 2: $\quad$ GC-FID of microwave irradiated samples.

Table 5: Energies of the reaction medium after 25 minutes microwave irradiation.

\begin{tabular}{|c|c|c|c|}
\hline $\begin{array}{c}\text { Sample } \\
\text { number }\end{array}$ & $\begin{array}{c}\text { Sample } \\
\text { composition }\end{array}$ & $\begin{array}{c}\text { Final } \\
\text { Temperature } \\
\left({ }^{\circ} \mathrm{C}\right)\end{array}$ & $\begin{array}{c}\Delta \mathrm{H} \\
(\mathrm{KJ} / \mathrm{kg})\end{array}$ \\
\hline \hline 1 & $\begin{array}{c}\text { AH50 Pure Crude } \\
100 \mathrm{~g}\end{array}$ & 53.80 & - \\
\hline 2 & $\begin{array}{c}\text { AH50 Pure Crude } 100 \mathrm{~g}+10 \% \\
\text { DEA }\end{array}$ & 193.6 & 362.1 \\
\hline \hline 3 & $\begin{array}{c}\text { AH50 pure crude } 100 \mathrm{~g}+1.5 \mathrm{~g} \\
\text { palladium catalyst }\end{array}$ & 228.8 & 437.1 \\
\hline 4 & $\begin{array}{c}\text { AH50 pure crude } 100 \mathrm{~g}+10 \% \\
\text { DEA } / 1 \mathrm{~g} \text { palladium catalyst }\end{array}$ & 298.8 & 586.2 \\
\hline 5 & $\begin{array}{c}\text { AH50 pure crude } 100 \mathrm{~g}+10 \% \\
\text { DEA/ } 10 \% \text { charcoal } / 1 \mathrm{~g} \\
\text { palladium catalyst }\end{array}$ & 305.9 & 601.3 \\
\hline 6 & $\begin{array}{c}\text { AH50 pure crude } 100 \mathrm{~g}+10 \% \\
\text { DEA/ } 15 \% \text { charcoal } / \mathrm{g} \\
\text { palladium catalyst }\end{array}$ & 381.6 & 762.5 \\
\hline
\end{tabular}




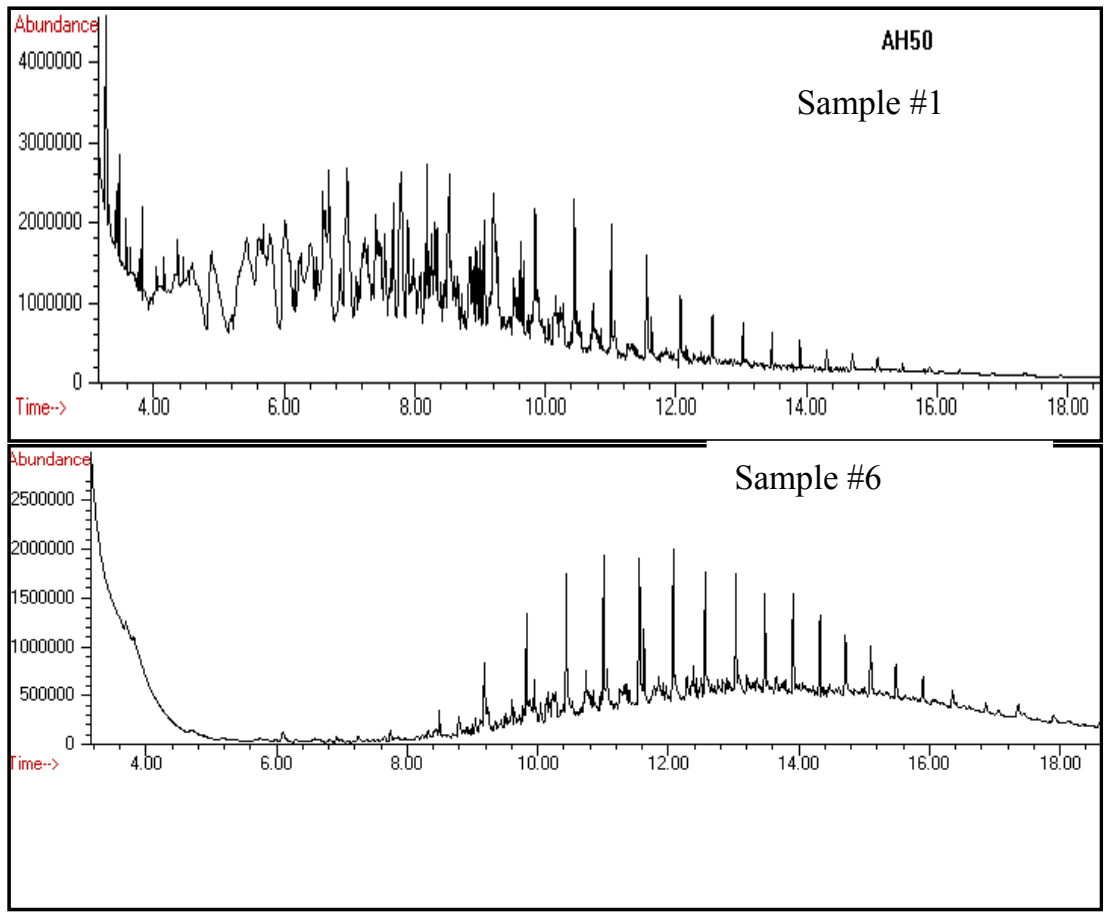

Figure 3: Comparison of GC-FID of pure heavy crude oil and crude oil sample containing additives irradiated for 25 minutes.

crude and other samples with lower reaction temperatures. These results suggest that the molecular structure of the sample has changed and higher molecular weight hydrocarbon chains were formed through chemical bonding.

With 15 per cent charcoal on palladium catalyst (sample \#6), the highest temperature of $381.6^{\circ} \mathrm{C}$ was obtained approximately 10 minutes into the set irradiation time of 25 minutes. Once this temperature was achieved, it decreased to $346.1^{\circ} \mathrm{C}$ over the remaining 15 minutes. The extra irradiation time allowed the reaction to proceed further causing the hydrocarbons to bond and create a higher molecular weight material. It appears that the optimum microwave irradiation time for this sample is 10 minutes which is when the highest temperature was reached. At this time, there might have been some breaking of the heavier hydrocarbons. Similar trend was obtained with sample \#5, attaining the temperature of $305.9^{\circ} \mathrm{C}$ in approximately 17 minutes before reducing to slightly lower temperature. Viscosity tests were conducted at $30^{\circ} \mathrm{C}$ for each microwave sample to verify and compare the changes in molecular nature of the crude at different microwave irradiation time. The results are shown in Figure 4 for three samples. Viscosity results do not explicitly confirm the presence of light fractions, but illustrate the strong possibility of abundance of high molecular weight hydrocarbons. This is an indication of the domination of recombination 


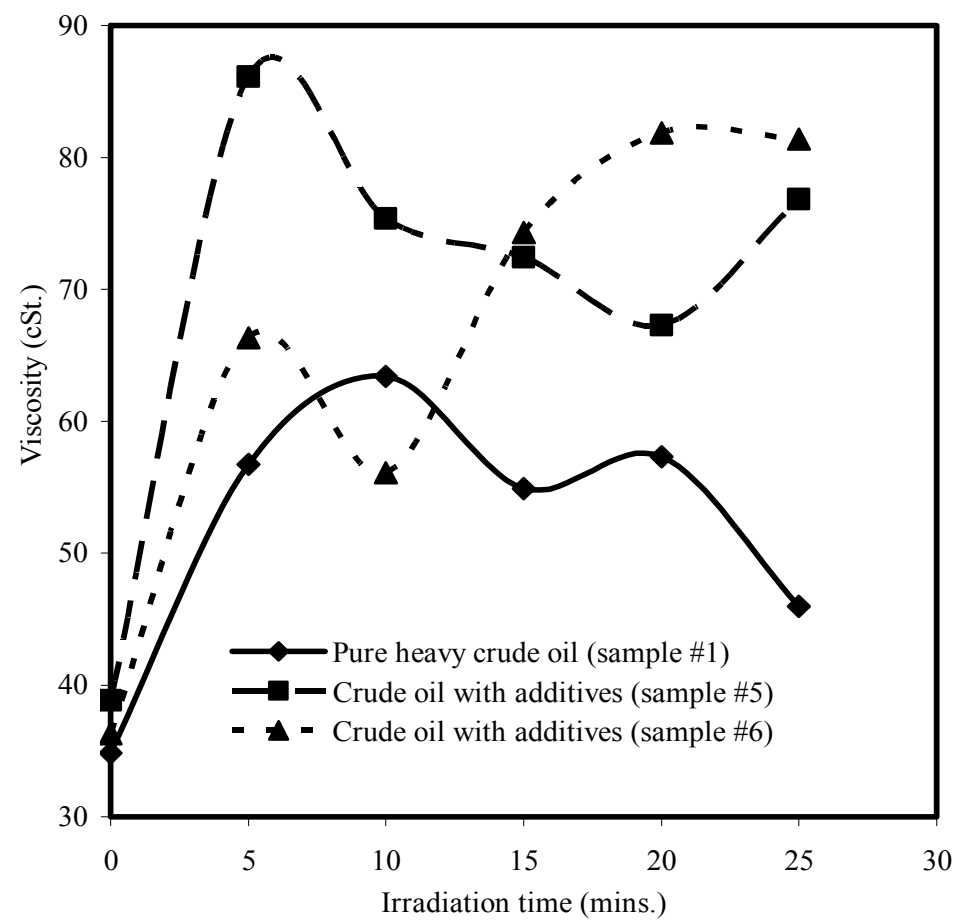

Figure 4: Comparison of viscosity of different samples exposed to different irradiation times.

reactions over fragmentation reactions in microwave process. This observation is in agreement with the GC-FID chromatogram obtained for irradiated and pure samples given in Figure 3.

\section{Conclusion}

The application of microwave irradiation process for desulphurization and upgrading of heavy crude oil is illustrated. The results show that sensitizers improve crude oil absorption of microwave radiation and that with appropriate composition of polar additive, catalyst and sensitizer up to $40 \%$ desulphurization is achievable. Erratic change in the viscosity of the heavy crude oil indicates the occurrence of fragmentation and recombination reactions at different irradiation time. Overall, the viscosity of irradiated samples is slightly higher than that of non-irradiated sample which means that recombination reaction is prevalent. This study shows that microwave radiation promotes both desulphurization and upgrading of heavy oil at low temperatures where similar reactions are not feasible by the thermal process. The optimum condition for desulphurization and upgrading of heavy crude oil by microwave irradiation depends on the composition and type of catalyst, microwave sensitizer, polar additive and 
irradiation period. For concurrent desulphurization and upgrading process 25 minutes irradiation time, $381^{\circ} \mathrm{C}, 10 \%$ ethanolamine, and $15 \%$ activated charcoal on palladium catalyst were identified as the optimum.

\section{Acknowledgements}

The authors thank Jamie Tunnicliff for assistance with the experiment, and gratefully acknowledge financial support from the Saudi Aramco Ltd, Cape Breton University Research Policy (RP) grant and the Natural Science and Engineering Research Council of Canada (NSERC).

\section{References}

[1] Panchenkov, G.M., Erchenkov, V.V., Radiation-Chemical Processes. Chemistry and Technology of Fuels and Oils, 16(7-8), pp. 433-436, 1980.

[2] Ashton, S.L., Cutmore, N.G, Rooch, G.J., Watt, J.S., Zastawny, H.W., McEwan, A.J., Development and Trial of Microwave Techniques for Measurement of Multiphase Flow of Oil, Water and Gas. SPE Asia Pacific Oil and Gas Conference, Melbourne, Australia. SPE paper N0.28814, 1994.

[3] Gunal, O.G., Islam. M.R., Alteration of Asphaltic Crude Rheology with Electromagnetic and Ultrasound Irradiation. Journal of Petroleum Science and Engineering, 26, pp. 263-272, 2000.

[4] Stanley, R.K., Methods and Results of Inspecting Coiled Tubing and Line Pipe. SPE/IcoTA Coiled Tubing Roundtable, Houston, Texas, SPE paper No. 68423, 2001.

[5] Zaykina, R.F., Zaykin, Yu-A., Radiation Technologies for Production and Regeneration of Motor Fuel and Lubricants. Radiation Physics and Chemistry, 65, pp. 169-172, 2002.

[6] Zaykin, Yu.A., Zaykina, R.F. \& Silverman, J., Radiation Thermal Conversion of Paraffinic Oil. Radiation Physics and Chemistry, 69, pp. 229-238, 2004.

[7] Zaykina, R.F., Zaykin, Yu-A., Mirkin, G., Nadirov, N.K. Prospects for Irradiation Processing in the Petroleum Industry. Radiation Physics and Chemistry, 63, pp. 617-620, 2002.

[8] Speight, J.G. The Chemistry and Technology of Petroleum, $3^{\text {rd }}$ edition. Mercel Dekker Inc., New York.

[9] U.S. Pat. \# 4,148,614, April 10, 1979; U.S. Pat. \# 4,749,470, June 7, 1988; U.S. Pat. \# 6,824,746; U.S. Pat. \# 4,279,722, Nov. 15, 1994; Belgian Pat. \# 481,341; Hungarian Pat. \# 19,498.

[10] asiinstr.com/technical/Dielectric constants.htm 